This is a self-archived - parallel published version of this article in the publication archive of the University of Vaasa. It might differ from the original.

\title{
Mixed signals : employee reactions to talent status communication amidst strategic ambiguity
}

Author(s): Sumelius, Jennie; Smale, Adam; Yamao, Sachiko

Title: $\quad$ Mixed signals : employee reactions to talent status communication amidst strategic ambiguity

Year: $\quad 2020$

Version: Accepted manuscript

Copyright (C)2019 Informa UK Limited, trading as Taylor \& Francis Group. This is an Accepted Manuscript of an article published by Taylor \& Francis in International journal of human resource management on 27 Feb 2019, available online: http://www.tandfonline.com/10.1080/09585192.2018.1500388.

\section{Please cite the original version:}

Sumelius, J., Smale, A., \& Yamao, S., (2020). Mixed signals : employee reactions to talent status communication amidst strategic ambiguity. International journal of human resource management 31(4), 511-538. https://doi.org/10.1080/09585192.2018.1500388 


\title{
Mixed signals:
}

\section{Employee reactions to talent status communication amidst strategic ambiguity}

\author{
Jennie Sumelius \\ Adam Smale \\ Sachiko Yamao
}

Accepted for publication in the International Journal of Human Resource Management

\begin{abstract}
Given the sensitive nature of communicating talent status in an 'exclusive' talent management system and the complexity involved in simultaneously sending signals of exclusivity and inclusivity, some organisations avoid open communication and instead opt for 'strategic ambiguity' - intentionally maintaining an element of secrecy and information asymmetry. However, we know relatively little about the effects of this communication approach as a feature of the organisational context on the reactions of employees. Drawing on signalling theory, we examine the reactions of both talents and ' $\mathrm{B}$ ' players on finding out about their talent status in the context of a company that adopts strategic ambiguity in its communication about talent. The data consists of 24 in-depth, qualitative interviews with individuals with experience of TM in a Finnish subsidiary of a large, US-based multinational corporation. The findings reveal that the contextual effects of strategic ambiguity in talent communication affected the reactions of talents and ' $\mathrm{B}$ ' players in distinctly different ways, but had few long-term positive effects on the attitudes and behaviours of either group. These findings present important theoretical and practical implications for the role of communication and organisational context in employee reactions to talent pool inclusion and for talent management more generally.
\end{abstract}

Keywords: talent management, multinational corporation, communication, talent status, employee outcomes 


\section{INTRODUCTION}

Research on talent management (TM) from the individual employee perspective has been limited (McDonnell, Collings, Mellahi \& Schuler, 2017), but has thus far revealed that employee reactions to talent identification can be mixed. Some studies find several positive attitudinal and behavioural outcomes among employees possessing talent status (Björkman, Ehrnrooth, Mäkelä, Smale \& Sumelius, 2013; Collings \& Mellahi, 2009; Sonnenberg, van Zijderveld, \& Brinks, 2014), whereas others find more negative outcomes in the form of increased expectations, selfsatisfaction and stress (Dries \& De Gieter, 2014; Petriglieri \& Petriglieri, 2017; Silzer \& Church, 2010; Tansley \& Tietze, 2013). This literature, as well as the TM practitioner literature (e.g. Fernández-Aráoz, Groysberg \& Nohria, 2011), emphasises the importance of communication in effective TM systems, yet the issue of how companies communicate about talent status to their employees has not been problematised or received much empirical attention.

Exclusive TM, defined here as "the differential management of employees according to their relative potential to contribute to an organisation's competitive advantage" (Gelens et al., 2013: 342), builds on the concept of workforce differentiation and implies a focus on a sub-group of 'talents' who are most likely to contribute significantly to organisational performance and who demonstrate the greatest potential to develop into future leaders (Gallardo-Gallardo, Dries, \& González-Cruz, 2013). However, this exclusive approach to TM complicates communication since companies must try to simultaneously signal feelings of both exclusivity and inclusivity: those in the talent pool need to feel valued and see some indication of exclusive treatment, whilst the larger group of 'B' players (employees not in a talent pool) need encouragement to maintain or improve their performance (Malik \& Singh, 2014).

Whilst popularised examples of multinational corporations (MNCs) such as General Electric and their "Session C" processes (Bartlett \& McClean, 2003) give the impression that 
communication about TM is typically open, candid and transparent, a growing body of evidence suggests that many firms are reluctant about communicating openly (Church, Rotolo, Ginther, \& Levine, 2015; Fernández-Aráoz et al., 2011). For example, in terms of 'B' players, openness can lead to concerns about potential negative reactions such as envy, decreased motivation, and turnover intentions, whereas for talents the concerns are that they may become complacent, selfsatisfied and develop potentially unrealistic expectations about their future (Dries \& De Gieter, 2014; Silzer \& Church, 2010). Amidst such fears, corporate communication about talent status can remain surprisingly vague and secretive. Indeed, some firms choose to employ a 'strategic ambiguity' in communication (Eisenberg, 1984; Dries \& De Gieter, 2014) - deliberately maintaining information asymmetry about who is 'talent' - on the basis that the advantages of not openly communicating about talent status outweigh the disadvantages. However, as a feature of the organisational context, the effects of strategic ambiguity on how employees perceive and react to TM are poorly understood.

In this paper, we draw upon 24 in-depth, qualitative interviews to examine the reactions of both talents and 'B' players on finding out about their status in the context of a company that adopts strategic ambiguity in its communication about talent. Our starting point is that differentiation between employees makes communication about talent status more complex and sensitive for the organisation. Although communication characterised by strategic ambiguity may be one alternative approach for dealing with this sensitivity, we problematise the assumption that the benefits of vague communication about talent status outweigh the costs.

More specifically, the study contributes to the TM literature in two main ways. Since the current theoretical and empirical base of TM is largely US based, calls have been made for more research on the extent to which current assumptions and concepts in the TM literature are appropriate for describing and studying TM in other national contexts (Collings, Scullion, \& 
Vaiman, 2011; Thunnissen, Boselie, \& Fruytier, 2013). Our study focuses on the consequences of an organisation adopting a talent communication approach built around strategic ambiguity in a Nordic context - Finland - characterised by strong, egalitarian values. In this way, the first contribution the study makes is to shed light on the impact of organisational and national context (Gallardo-Gallardo \& Thunnissen, 2016) on the implementation of TM, and the effects this has on employee outcomes at the individual level.

The second contribution is to our understanding of how those subjected to TM (Swailes \& Blackburn, 2016) react to communication about talent status. Drawing on signalling theory (Connelly, Certi, Ireland \& Reutzel, 2011), we illustrate the effects of strategic ambiguity by shedding light on the number of different interpretations and reactions, both desired and undesired, that it gives rise to among both talent and ' $\mathrm{B}$ ' players. This responds to calls for research on TM to adopt a more pluralistic view (Thunnissen et al., 2013,), since with some exceptions (e.g. King, 2016) the employee perspective remains under-examined (Dries, 2013; McDonnell et al., 2017). We extend this further by incorporating the reactions of 'B' players (Delong \& Vijayaraghavan, 2003; Malik \& Singh, 2014).

\section{COMMUNICATION OF TALENT STATUS}

\section{Employee reactions to talent identification}

Similar to how the HRM process school emphasises the key role of employee perceptions in determining the strength of an HRM system (Bowen \& Ostroff, 2004), employees - the targets of TM - are a crucial link in understanding the impact and effectiveness of TM practices (Swailes $\&$ Blackburn, 2016). This is because employee perceptions of practices rather than the practices themselves are more likely to influence employee attitudes and behaviours. King (2016) describes this in terms of employee responses to the 'talent deal', which is argued to be a 
significant 'career event' capable of altering the psychological contract. Whilst rather piecemeal, there is a growing strand of the TM literature that examines individual talent perspectives (McDonnell et al., 2017).

On the one hand, studies identify positive outcomes among those identified as talent. This includes a greater willingness to take on demanding assignments, building valuable competencies, supporting strategic priorities, organisational identification, and lower turnover intentions (Björkman et al., 2013), as well as increased work motivation and commitment (Collings \& Mellahi, 2009) and greater efforts to fulfil the psychological contract (Sonnenberg et al., 2014).

On the other hand, an exclusive approach to TM is associated with certain problems. Talent status awareness has been empirically shown to make talent more complacent, arrogant, increasing their expectations towards the organisation (Dries \& De Gieter, 2014; Ehrnrooth et al., forthcoming) and their feeling of pressure and stress (Tansley \& Tietze, 2013). Concerns have also been voiced regarding the potential negative reactions of those not identified as talent, including outcomes such as disengagement (Silzer \& Church, 2009), decreasing motivation and performance (Gelens et al., 2013; Nijs, Gallardo-Gallardo, Dries \& Sels, 2014) and increasing jealousy and frustration (Dries \& De Gieter, 2014, Malik \& Singh, 2014).

One potential reason behind the contradictory findings which is alluded to in both the academic (e.g. Björkman et al., 2013) and practitioner literature (e.g. Petriglieri \& Petriglieri, 2017) is the role of communication.

\section{Talent communication, signalling theory and strategic ambiguity}

In line with research into HRM process and signalling theory (Guzzo \& Noonan, 1994), how organisations and managers communicate about TM sends signals to employees about what 
is expected, valued and rewarded (Bowen \& Ostroff, 2004; Guest \& Conway, 2002; Sonnenberg et al., 2013). These signals play important roles in how employees perceive and respond to HRM practices such as TM and the attributions they make about them (Nishii et al., 2008).

Signalling theory is broadly concerned with understanding how parties resolve information asymmetries and is thus useful in making sense of behaviours (of individuals or firms) when two parties have access to different information (for a detailed review see Connelly et al., 2011). A central tenet of signalling theory is that a signaller obtains information not available to outsiders, but that outsiders might find useful (Spence, 1973). The signaller can then choose whether and how to signal this information to the other party, the receiver. The signaller may decide to withhold the information to occupy a privileged position, or the signaller may decide to send a signal to a receiver, who then needs to decide how to interpret the signal.

$\mathrm{TM}$ is an intriguing context in which to examine the sending and interpreting of signals. There is mounting evidence to suggest that many firms are hesitant to send clear signals about talent status (Dries \& Pepermans, 2008; Gelens et al., 2013; Festing, Kornau \& Schäfer, 2015) and, instead, employ various forms of 'strategic ambiguity' in their communication with employees (Dries \& De Gieter, 2014). Eisenberg (1984: 230) defines strategic ambiguity as "those instances where individuals use ambiguity purposefully to accomplish their goals". Although effective communication is often equated with open communication, Eisenberg (1984: 230) argues that clarity and openness are de facto nonsensical standards for effective communication, and only suitable as measures of communicative competence if one has as the goal to be clear.

Organisations may for strategic reasons prefer to communicate ambiguously to employees to allow for multiple interpretations. In such instances, organisations may work on the assumption that the costs/benefits of not communicating talent status are more favourable 
compared to communicating it. From the organisation's viewpoint, it might thus be preferable to send weak signals about talent status (who is 'talent') since this information asymmetry allows unconfirmed assumptions to persist. Similarly, ambiguity about the criteria for talent pool inclusion provides supervisors with more discretion when nominating candidates (Dries \& De Gieter, 2014), whereas clear and transparent criteria may result in an excessive number of eligible candidates, decreasing the exclusivity of talent status and creating difficulties in providing development opportunities for large numbers.

From the perspective of the individual employee, one could make a case for keeping employees in the dark about their careers as being "shortsighted, if not unethical" (Pucik et al., 2017: 249; Guest, 2017; Swailes, 2013). Furthermore, Dries and De Gieter (2014) found that, even when talents are informed of their status, they tend to be confused by their organisations' ambiguous communication as to the actual implications of talent status. This kind of ambiguity seems misaligned with the commonly stated goal of talent identification, namely retaining, motivating and increasing commitment among key employees through differentiation.

Taking a communication perspective, Guzzo and Noonan (1994) argue that HRM practices (such as TM) continuously send signals from the company in both intended and unintended ways. This communication can be explicit, for instance in the form of e-mails and mission statements, or implicit in the form of organisational culture and employee observation (Suazo, Martínez \& Sandoval, 2009). In the presence of multiple signallers and multiple signals, the organisation only has partial control over the signals that form the basis of employee interpretations and behaviours.

Irrespective of which kind of formal communication strategy the organisation chooses, receivers are likely to engage in their own additional information acquisition processes which might include 'grapevine communication activity' (Dries \& De Gieter, 2014: 151). This may 
undermine both the organisation's goals regarding TM, as well as employees' trust in the organisation more generally. Research on the role of communication and transparency for perceived justice of TM programmes suggests that justice perceptions are more positive when there is open communication to all employees (Gelens et al., 2013; Slan-Jerusalim \& Hausdorf, 2007).

Extant research clearly suggests that TM communication is both important and complex, yet there is much we do not know in terms of how communication influences employee perceptions of talent status and how this unfolds. We also know relatively little about the impact of national and organisational context on the outcomes of TM implementation at the employee level. We address these limitations in TM research by examining the effects of strategic ambiguity in TM communication, which is a distinctive feature of the organisational context of our study, and an approach rooted in the values of the Finnish national setting.

\section{METHOD}

This study is based on interviews with individuals (both talent and ' $\mathrm{B}$ ' players) with experience of TM in the Finnish subsidiary of a large US MNC. We chose to focus on employees with a background in the same organisation to gain an in-depth understanding of the subject matter (i.e. employees' reactions to talent status) and the impact of a particular organisational context. This is because TM policies regarding the communication of talent status are known to vary among organisations between very secretive to very open (Dries \& De Gieter, 2014). By focusing on employees within one company, we aimed to minimise the influence of exogenous factors stemming from differences between organisations. Focusing on individuals' experiences of TM in FinnTech was suitable for studying reactions to finding out about talent status in an organisation that has an exclusive approach to TM and adopts an approach of strategic ambiguity 
in talent status communication. Also, our context allowed for the cross-cultural examination of how a US-based TM system is viewed by talents and ' $\mathrm{B}$ ' players in another national context.

\section{Research context}

\section{Talent communication in FinnTech}

The organisational context of our study, hereafter referred to as FinnTech ${ }^{1}$, is a medium-sized Finnish subsidiary of a large, US-based MNC that operates in the technology sector, with subsidiaries in more than 50 countries. FinnTech invests considerably in training and development across its global operations. Talent pools are the most exclusive development opportunity and multiple pools exist at the local, regional, and global levels, and at different ranks in the organisation.

The global corporation adopts a communication strategy throughout its global operations that is characterised by strategic ambiguity. In FinnTech, this means that only employees identified as talents are formally notified about their status. Apart from this, FinnTech does not formally communicate to employees (talent or 'B' players) about the existence of talent pools, or about the implications of being labelled talent. Talents therefore know about their own status as talent but little more. The news of their status is communicated to them face-to-face by their supervisor in the annual development discussion. Following this, they receive a standardised email from HR informing them of their acceptance into a talent pool, and listing talent activities (e.g. workshops, training events) they will be expected to attend. Talent activities and benefits

\footnotetext{
${ }^{1}$ Since TM is directly linked to a company's strategic capabilities, and differentiating between employees is a sensitive matter, our case organisation and all interviewees are treated anonymously, and we refrain from disclosing more in-depth details about the company.
} 
include joint workshops with leadership, increased networking opportunities with senior managers, eligibility for special training sessions, and being prioritised in cases of new internal positions.

For the ' $\mathrm{B}$ ' players, there is no formal corporate communication about their status. Their knowledge of corporate talent activities, and their own and others' talent status, if any, is based on unofficial information from informal channels such as the organisational grapevine or by talking to colleagues.

\section{The Finnish context for talent management}

With a population of 5.5 million, Finland celebrated its 100 years of independence in 2017. Having been a predominantly agrarian economy in the 1950 's, it has rapidly developed into a prosperous knowledge economy. Finland is currently ranked sixth on the Global Talent Competitiveness Index (GTCI 2018) out of 119 countries, indicating the country's high ability to attract, develop and retain the human capital that contributes to its productivity (Lanvin \& Evans, 2018; Khilji, Tarique \& Schuler, 2015).

One of the hallmarks of modern-day Finnish society is strong egalitarian values. This is reflected in many ways, not least in the focus on achieving social mobility and equal opportunity. Finland again performs well here, ranked number one in social mobility and number two in the Global Gender Gap Index (2016) according to reports by the World Economic Forum. Based on a 'no child left behind' principle, equity has been a cornerstone of Finnish education policy since the early 1970's and is reflected in the high degree of personalised teaching support for all students (particularly those who find it hard to keep up) and the fact that performance differences between schools in Finland are among the smallest in the world (Sahlberg, 2015). The emphasis on egalitarian values and respect for others, instilled from a young age, is evident in Finland's 
low power distance scores, and is one explanation for why modesty is a particularly strong virtue in Finnish culture.

Whilst individual performance-based compensation is fairly commonplace in Finland, the above features of Finnish society have meant that exclusive TM practices do not sit very comfortably in Finnish organisations. As indicated in recent empirical work on TM in Finland (e.g. Björkman et al., 2013), most Finnish organisations that have TM systems in place typically do not communicate openly about status and workforce differentiation practices.

\section{Research design and data collection}

Interviews were carried out with 24 individuals with experience of the TM system at FinnTech between January and August 2016. Since our focus was on employee reactions, we decided to target managers and professionals currently working in the company, and with at least one year of tenure to allow for sufficient time to build an understanding of corporate TM. Later, we extended this to include individuals who had left the company within the last 12 months ${ }^{2 \text {. These }}$ individuals might provide us with a broader variety of reactions, potentially from talents who had left due to unmet expectations, as well as ' $\mathrm{B}$ ' players who perhaps had left the organisation because of finding out they were not in a talent pool. Further, TM as a topic is likely to be sensitive for current employees since it concerns differentiation and personal status in the organisation, whereas former employees, especially 'B' players, might find it less sensitive to talk about their experiences after some time had passed.

\footnotetext{
${ }^{2}$ We chose 12 months as the cut-off point since we judged that the TM system of the company, as well as views of talent status communication, would still be relatively fresh in the minds of individuals who had left.
} 
At the start of each interview, we did not know if interviewees were talents or ' $\mathrm{B}$ ' players. Rather, this emerged during the interview. Thus, in the context of this study we rely on selfreported talent status. This approach is similar to previous studies (e.g. Björkman et al., 2013), and based on the argument that individuals' own perceptions of whether or not they are labelled as talent is what drives their subsequent attitudes and behaviours. Since talents received explicit communication from the organisation (an e-mail from the HR department) about having become included in a talent pool, it was obvious to them that they were talent in the eyes of the organisation. For 'B' players, the message was more implicit. Through informal organisational communication such as the corporate grapevine and talking to colleagues, some of who were talents, they picked up cues about the existence of an exclusive talent programme in the company and what it involved for those included in terms of participation in special projects and trainings. As they derived more and more information ' $\mathrm{B}$ ' players drew the conclusion that they were not talents since they had not received any communication from the organisation stating the opposite and were not involved in any special projects.

We used our personal networks and the snowballing technique (Patton, 2015) to contact people for interviews. We started out by contacting two individuals who we knew from before, with a background in FinnTech. We then asked them to refer us to other individuals either currently employed at FinnTech, or who had left the company within the past year. Subsequent potential interviewees were contacted via e-mail in which the focus of the study was briefly explained: employee perceptions of TM in FinnTech in general and talent status in particular. These individuals then provided information to others potentially interested in participating, resulting in a total of 24 interviewees. Out of these, 11 individuals were current employees of FinnTech, and 13 individuals were former employees. Twelve were men and 12 were women. Seventeen (nine men and eight women) had been formally notified by the organisation of their 
talent status. Of the seven interviewees who had not received any notification from the organisation, but rather found out about their status as 'B' players through informal channels, four were women and three were men. They were all former employees of the company. Most interviewees (20) had a managerial role while four had a technical role (two of these were talents and two were 'B' players). The organisational tenure of interviewees ranged between 3 and 16 years with an average of 6.6 years. There was no difference in tenure between talents and 'B' players.

The interviews adopted a semi-structured format, following an interview guide with purposefully open-ended questions, designed to allow for considerable flexibility in the conversation depending on matters interviewees found relevant to raise (Miles \& Gilbert, 2005). Based on previous work on positive and negative implications of talent status awareness (Collings \& Mellahi, 2009; Dries \& De Gieter, 2014; Ehrnrooth et al. forthcoming; Gelens et al., 2013; Nijs et al., 2014), we wanted to gain a more in-depth understanding of how talents and 'B' players reacted to finding out about their talent status. We first asked about the interviewees' professional background, organisational tenure and their experience of TM in previous places of employment if they had any. We then asked interviewees about the TM system at FinnTech, and in doing so almost all interviewees mentioned their talent status unprompted. The flow in the interviews was similar for both talents and 'B' players. In most cases, interviewees carried on talking more about their status. Otherwise, we prompted them with follow-up questions about how they found out about their status, how it made them feel, what they perceived to be the central implications of being/not being in a talent pool, and if it affected their daily work. In a few instances, interviewees started out by describing their own skills development but did not move on to mention TM or their own status. In such cases, we reiterated our original question about what the company does to manage talent. We were prepared some of the ' $\mathrm{B}$ ' players might 
find the issues of talent status sensitive to discuss. However, this was not the case and ' $\mathrm{B}$ ' players did not mind talking about their (non-)status, even though this had been disappointing to some of them. This is possibly due to all 'B' players in our sample were former employees of FinnTech who had found new employment elsewhere.

The interviews were carried out by one of the authors and a research assistant. Nineteen interviews were conducted face-to-face, and five over the phone. The confidentiality and anonymity of the interviews were emphasised, and interviewees were given the possibility to sign a letter of confidentiality, which 15 interviewees did while the others were satisfied with our verbal promise of anonymity in reporting results. We further explained that the interviewees were participating in the study as individuals rather than as company employees, and that our focus was on individual perceptions of TM and talent status. The interviews lasted between 20-120 minutes, with an average duration of 40 minutes. Although the interviewees' mother tongue varied (most were native Finnish speakers), the majority of interviews were held in English ${ }^{3}$. Since FinnTech's corporate language is English, we assumed interviewees would have a good command of the language, which turned out to be the case. All interviews were digitally recorded with the interviewees' permission, and verbatim transcribed.

\section{Data analysis}

There is no definitive set of guidelines for analysing qualitative data (Bryman, 2015; Patton, 2015). Consequently, following Maitlis and Lawrence (2007) and Barley, Meyerson, and Grodal

\footnotetext{
${ }^{3}$ We gave the interviewees the opportunity to be interviewed in Finnish or English (with the explanation that English was the project language). This resulted in six interviews being conducted in Finnish, and the rest in English.
} 
(2011), two of the authors analysed the data in two broad phases as described below, acknowledging the iterative nature of qualitative data analysis and the blurred boundaries between the phases (Barley et al., 2011). In the actual data analysis, we followed Strauss and Corbin's (1998) grounded theory approach since this methodology allows both induction and deduction in the analysis. We relied on signalling theory in developing our conceptual frameworks for summarising the core findings that emerged from the data.

Phase 1: In the first phase, we aimed to develop an initial overall understanding of the data. We started by reading and rereading the interview transcripts as soon as they were ready. We created a table in which basic information about each interviewee was included, such as his/her current or last held position in the company, tenure in that position, talent status currently and previously, and previous experience of TM systems in other companies. Following Strauss and Corbin's (1998) coding scheme, we first conducted an open coding and identified excerpts in the interviews that were relevant to the themes of this study (how individuals found out about their status as talents or ' $\mathrm{B}$ ' players, how they reacted to this knowledge). We included these excerpts in the initial coding table, grouping them under rough headings in line with how employees talked about them. These varied from an overview of FinnTech's TM to the different emotions interviewees experienced.

Phase 2: In the second phase we performed a raw analysis of the data by identifying emerging themes and creating an initial coding table. Examples of the coding and interpretations are presented in Table 1. Simultaneously, we conducted axial coding (Strauss \& Corbin, 1998) in which we merged similar themes into more abstract categories. For instance, we saw different kinds of comments related to cross-cultural differences between the US and Finland. During this process, the sense of guilt talents felt towards 'B' players came under a more abstract code of cross-cultural difference as we interpreted that the sense of talents' guilt derived from the 
egalitarian nature of the Finnish culture. To ensure the quality of our coding, the next step was to triangulate investigators (Andersen \& Skaates, 2004). We did this by swapping tables, reading through the table compiled by the other and comparing our interpretations before further refining the codes. In the final stages of selective coding (Strauss \& Corbin, 1998), we selected core categories that were deemed most important for the conceptual grounds of the current study (i.e., strategic ambiguity of TM and signalling). These core categories were integrated to develop Figures 1 and 2 presented in the findings section.

\section{-INSERT TABLE 1 ABOUT HERE-}

\section{FINDINGS}

When analysing our data, we observed that the impact of strategic ambiguity and individuals' reactions occurred very differently for talents compared to ' $\mathrm{B}$ ' players. We therefore present the findings separately for talents and 'B' players and illustrate our analyses with direct quotes from the interview transcripts to show how we made our interpretations ${ }^{4}$ (Patton, 2015; Pratt, 2009). Both sections follow the same structure in that we first describe how each group found out about their talent status, their immediate reactions, and finally their longer-term sensemaking of the implications of their talent status. This separation between shorter and longer-term reactions emerged from the data. Importantly, we note that although sensemaking has been defined in various ways (Maitlis \& Christianson, 2014), in this paper we view it as a cognitive process of constructing understandings of experiences (Starbuck \& Milliken, 1988). Furthermore, whilst

\footnotetext{
${ }^{4}$ To improve the readability of the quotes presented, some grammatical corrections have been made, and some quotes have also been translated from Finnish to English.
} 
these issues were the explicit focus of our study, and questions about them were included in our interview guide, the issue of the Finnish cultural context emerged unprompted throughout our discussions with the interviewees. We thus conclude with a section on how some of the interviewees' reactions seem to have been influenced by the Finnish context.

\section{Reactions of talents to talent status communication}

The signalling environment for talents in FinnTech was formal, meaning that signal observability for them as 'insiders' was high. Many talents expressed a degree of sympathy for the company's policy of not communicating openly to everyone about talent pools, mentioning that it might risk causing jealousy and envy amongst those not recognised, contribute to a negative atmosphere in the unit, and "create the wrong kind of tension between some people" (Int. No.5, current employee, member of a talent pool). Despite the consensus of not openly naming employees currently in a talent pool, talents agreed that the inclusion criteria should be explicitly communicated to all to signal transparency and fairness of corporate TM practices. Some also expressed discomfort with FinnTech's secretive approach to communicating about talent. One interviewee commented as follows:

“[...] It wasn't right, it felt like somebody is pregnant and you can't say it aloud after three months or something. Like there was this kind of weird, not lies, but weird kind of communication where you understand that okay, you're not coming to the office on Monday because you are with the 'talents' somewhere on a training exercise. So it was like everyone understood what was going on." (Int. No. 13, former employee, member of a talent pool)

The immediate reactions of the talents (signal receivers) upon being informed by their managers (signallers) of inclusion in a talent pool can be described as twofold. In general, the immediate first reaction was, not unexpectedly, a positive one comprising feelings of happiness, pride, and a sense of achievement. Several talents interpreted the status as a signal of the 
company's trust recognising their work and linked this further to feelings of increased self-esteem and confidence.

The initial excitement of having gained recognition was, however, swiftly followed by a longer-term process of analysing the actual meaning of this status (see Figure 1). Since the information of having been recognised as talent was not accompanied by any further details, they embarked on a process of sensemaking over what it would mean for them. This seemed to be the point at which they experienced considerable ambiguity about the actual implications of their exclusive status. Interviewees specifically mentioned a lack of clarity about the criteria for talent pool inclusion, giving rise to questions related to identity and social comparison, such as why they had been included, and who else had been included in a talent pool. Further, the duration of the talent status/programme, and the content and value of the talent programme seemed to lead talents to question/re-evaluate the psychological contract with the organisation.

\section{-INSERT FIGURE 1 ABOUT HERE-}

Commonly, the first source of ambiguity mentioned by interviewees concerned the criteria for being included in a talent pool. The comment below is a typical representation of the talents' reactions upon hearing their status and shows the transition from the initial feelings of "Wow!" to the more puzzled "Hmm?":

"I think the first feeling I had was that I'm so happy that I'm recognised for my good work. The second feeling I had was like, okay, what does this mean, does it mean extra work now that I'm in some kind of programme and we're going to be doing stuff with the management team? [...] And I'm like uh-oh [...] And the third feeling I had was, who else is there? Because I didn't know about it and I was thinking, what do you need to do to be there? Because it wasn't explained, what I'd done, it was just like 'yeah, you've been identified as this kind of talent'. ' (Int. No. 2, current employee, member of a talent pool) 
Whereas the talents generally made sense of their status in terms of having performed well in their jobs and achieving the goals set for them, several also mentioned face value and the importance of the relationship with the supervisor as probable criteria for talent pool inclusion. Being labelled talent also appeared to trigger a form of justice-related social-comparison process for several interviewees, regarding why they had been recognised and why certain other colleagues had not although they were perceived to be deserving of this status. Some also pondered over personal identity issues and the match between their own values and those of other talents, suggesting they did not consider themselves 'typical talent'. As a response to interviewer prompts about their meaning of 'typical talent', interviewees commonly mentioned being good at image building and marketing yourself internally to managers:

"[...] But then I start thinking that, are some of the people who are recognised promoting themselves too much. I don't know if this makes any sense to you but [...] that's the dilemma I've been having, I think, not only with the talent programme but also with the company to be very honest. Yeah, what kind of talent succeeds? Is it true talent or is it talent that is just very kind of, well, positioning themselves in the company?" (Int. No 2, current employee, member of a talent pool)

In addition to not being aware of the criteria for talent pool inclusion, talents were also not aware of the duration of their status, and what was required to maintain it. Some mentioned a set duration of one or two years, whilst others said they were not aware of any time frame and that this was a source of unease, paired with the unclarity of what they needed to remain in the group. Much of the ensuing sensemaking was framed around social exchange and perceptions of what the 'new' psychological contract between them and the organisation would mean. Several interviewees said they worried about things like an increased workload. Talent status was seen to place one increasingly in the internal corporate spotlight in terms of having to act as examples for other employees and having extra visibility in the eyes of management. Interviewees said they 
became more conscious of their actions at work since they felt they were under scrutiny, and experienced pressure to invest additional time in their work to prove they were deserving of the special status. One interviewee who used to be in a talent pool, but removed from it after a couple of years, commented as follows:

"[...] I didn't know what the criteria were to get in or out. I didn't know. But then I had a discussion with HR and they just announced that you are not talent anymore, and it wasn't clear, they didn't say that you are now out of the programme, they just said that maybe it's good that you are not part of the programme anymore. It was a very weird feeling, like, are you like asking me, or [...]. It was very weird. So I didn't know how you get in and didn't know how you get out." (Int. No. 1, current employee, member of one talent pool and previous member of another)

The final main source of ambiguity experienced by talents concerned the content and value of being talent. There was widespread agreement that the main benefit of being talent was gaining recognition. This was considered to provide better possibilities for internal networking and improved career advancement opportunities. In addition, talents also received a special bonus. Corporate talent activities were not perceived as particularly rewarding, but rather as something HR simply needed to find for talents to do together. Examples included working as a group to prepare corporate kick-off meetings, participating in the planning of new work premises, and teamwork to solve specific corporate strategic problems for the top management team.

Interviewees perceived a lack of focus on personal development in the talent activities, commenting that they were all group-based with no debrief analysing the success of the group work. All talent activities constituted an extra workload on top of their existing jobs and thus interviewees wondered whether talent status should really be perceived as a reward or a punishment. From a psychological contract perspective, it seemed clear that status was associated with more work, whilst the benefits, apart from recognition, were perceived as vague. As one employee who had been a member of several corporate talent pools in FinnTech expressed it: 
"I might be a bit of a pessimist because of this latest "Hey, you are part of this group now." I was like Jesus Christ how many of these do we have?! Again! (laughs). And I had a very honest conversation with my manager where I said I'm already part of this key talent group, and now this [...] I was a bit sceptical; is somebody just giving you a gold medal and scratching you behind the ear and saying 'good boy' (laughs), or is it something that's actually beneficial for me and for my career path..." (Int. No. 5, current employee, member of several talent pools)

\section{Reactions of 'B' players to talent status communication}

Contrary to talents, who received formal communication about having gained talent status, 'B' players received no formal communication about their 'non-status'. The signalling environment in their case can be described as informal, and signal observability as weak. This served to increase the importance of receiver attention and interpretation, since 'B' players needed to rely on subtle, weak and unintended signals to learn about their status. The self-awareness of ' $\mathrm{B}$ ' players' talent status emerged through a blurred, iterative process of discerning and analysing subtle signals in organisational activities, and gossip and informal messages from multiple signallers - colleagues in the organisational grapevine (see Figure 2). Information about talent status seemed to spread via a combination of the following: i) talking to colleagues, ii) observing 'out of the ordinary' events in the company such as preparations for a kick-off day or workshop (a typical activity assigned to groups of talent), or the sudden and unexplained absence of team members (who turned out to be attending invitation-only talent-training sessions elsewhere), and iii) seeing public invitations for talent activities in colleagues' share online calendars. An interviewee described one such situation:

"I just wondered - when I tried to book a meeting with a colleague and saw that he's attending some DEV stuff - what is that? So I just put the acronym into the intranet search and okay, then I found out what it was all about. Someone could say it's stalking, but (laughs) I was interested." (Int. No. 7, current employee and member of a talent pool) 
The contextual effects of strategic ambiguity were thus experienced continuously by ' $\mathrm{B}$ ' players, characterised by an ongoing cycle of evaluation and re-evaluation of one's own status and that of others. Drawing conclusions about one's status as a 'B' player, based on various informal cues, resulted in considerable speculation. ' $\mathrm{B}$ ' players thus also acted as signallers to others and contributed to the distortion of communication via participation in the organisational grapevine.

\section{-INSERT FIGURE 2 ABOUT HERE-}

Whilst some ' $\mathrm{B}$ ' players claimed indifference upon having figured out they were not talent, saying that they perceived themselves to have enough development opportunities anyway, most mentioned feeling disappointed. Their disappointment was amplified by not having received any formal communication from the organisation about the matter, so in addition to experiencing negative feelings about not being talent, it felt discouraging to have not even been informed about the existence of talent pools. This in turn, triggered feelings of resentment. As one employee described it:

"It was disappointing to see that this is how it works and I'm not part of it. Because earlier I was not that disappointed, I thought that I'm too old, but then I realised that even though I'm a good sales person and I was overachieving my targets, I was facing the fact that most probably I didn't have a future in the company. Not at least in the long run. So that was a bit, that was upsetting, I would say." (Int. No. 15, former employee, not a member of a talent pool)

Similar to talents, 'B' players pondered over why they had not been included, while someone else had. Contrary to the identity-related questions this raised among talents, 'B'players seemed primarily concerned about issues related to social comparison and fairness. The criteria for talent pool inclusion were generally considered non-transparent and/or non-existent. 
Disappointed, their perceptions about the credibility of the TM system were very critical. Some used the word 'pärstäkerroin' (roughly translated as face value) to explain that talent pool inclusion in their view was more commonly a result of image-building and knowing the right people, rather than being merit-based. Often couched in feelings of resentment, acquiring talent status was described as being contingent on being 'loud', 'self-promoting', and 'non-critical' towards the company:

"Yes, it's a negative word ("pärstäkerroin") but it feels like it was precisely those who were able to use the right adjectives, for instance "super-excited" was a good adjective to use in all e-mails, that you were "super-excited" about everything and that everything was wonderful and fantastic, never anything negative; everything the company did was simply fantastic. It felt like those who were on good terms with managers were accepted into it [the talent pool]." (Int. No. 19, former employee, not a member of a talent pool)

The above quote could be interpreted in two ways, first as an example of cognitive dissonance; 'If this is what being talent means, then I didn't want to be talent in the first place' (sour grapes). Second, it is an example of dis-identification from, or de-valuing of, the in-group: 'This is what talents are like, and that is not who I am'. Nonetheless, 'B' players pondered over the implications of not being talent for the psychological contract between them and the organisation, and the potential effects of this on their career in general. Some of the former employees said it had directly triggered them to start looking for work externally.

\section{Reflections of talents and ' $B$ ' players on TM in the Finnish context}

The cultural context of TM emerged as substantial in understanding the reactions of employees. Many interviewees had previous experience of working in other US companies and repeatedly compared their views of the Finnish and US-style corporate cultures during the interviews.

Several talents and 'B' players raised the issue of FinnTech's US corporate culture, in terms of 
working and building a career in the company, and of TM more specifically. The perceived need for self-promotion to be successful in a US company such as FinnTech was frequently discussed and appeared to be a source of discomfort for many who admitted they did not sufficiently selfpromote:

"I actually feel that I probably should have been there [in a talent pool] earlier, but I was not as good as the Italians or the Spanish in marketing myself into that pool of people..." (Int. No. 12, former employee, member of the talent pool)

Furthermore, describing feelings of pride and achievement upon hearing of their status, talents all emphasised the importance of remaining modest and maintaining a low profile. Many thought this was particular to the Finnish context, and they perceived this to vary in other parts of the MNC, such as in the US or southern Europe, where people were perceived to be more openly proud about the talent status. When pondering over if and how the knowledge of her own talent status had influenced her own behaviour in any way, one interviewee responded as follows:

"No, not really, it can't. At some point you get arrogant, but this company has a good way of keeping your feet on the ground. And of course, I'm not that kind of person that I go there and say, 'Oh look me, I'm a talent!' and make an example of myself like American people do for example." (Int. No. 7, current employee, member of a talent pool)

The interviewees commonly reasoned: i) it is inappropriate to flaunt a special, high status, such as talent as it is not in line with the Finnish way; and ii) in addition to the perceived appropriateness of being 'modest like a Finn', there is in the Finnish context a high likelihood that anyone showing an indication of thinking they are better than others becomes a target for collegial contempt. This line of thinking can perhaps best be described by the "Law of Jante" (Sandemose, 1933) - a term used widely in the Nordic countries to describe a condescending attitude towards individuality and success. It refers to a mentality of discouraging those who stand out as achievers, and instead emphasises the role of the collective rather than the individual 
in achieving success. One interviewee recounted the story of a colleague who felt bad about being the only one from a team to be singled out as talent, even though the team had worked together closely on the same project, the success of which was contingent on a team effort. Others said they experienced some embarrassment over being, what they considered, overpraised when they were simply doing their job like other colleagues:

"Of course it's flattering [to be recognised as talent] but the thing with an American company is that sometimes there are too many superlatives used, so for me as a Finn, if someone describes me with too many superlatives I get a bit uncomfortable because that's not in our nature." (Int. No. 3, current employee, member of a talent pool)

Based on our findings, we now move on to discuss the implications of adopting strategic ambiguity in communicating about talent status.

\section{DISCUSSION AND CONCLUSIONS}

Whilst existing academic and practitioner literature tends to highlight the positive effects of talent identification (e.g. Gelens et al., 2014; Fernández-Aráoz et al., 2011), we problematise this and provide a more nuanced view of the phenomenon by considering how talent status is communicated to employees. Focusing specifically on strategic ambiguity as an approach for communicating about talent status, we shed light on how this feature of the organisational context influences the attitudes and behaviours of both talents and 'B' players (Gelens et al., 2013). Our findings reveal that the effects of strategic ambiguity on employee reactions are markedly different for talents versus ' $\mathrm{B}$ ' players, yet in both cases the longer-term consequences were mostly negative from the individual's point of view. The findings further demonstrate how strategic ambiguity as a feature of the organisational context impacts the conceptualisation, implementation and effectiveness of TM in a specific national context. 
For talents, strategic ambiguity was most felt some time after having been informed of their status. At this point, short-term, largely positive reactions transformed into a longer-term phase of uncertainty and personal sensemaking about the meaning of the status, raising questions related to identity, and resulting in ongoing re-evaluations of the psychological contract. Indeed, strategic ambiguity accentuated the psychological nature of the exchange terms in the absence of formal, explicit communication. We observed several examples of what King (2016) refers to as employees assessing the 'talent deal' being presented to them. Whilst talent status can be, and was seen as, a signal of the employer's commitment towards talents (Björkman et al., 2013; Sonnenberg et al., 2013), talents' initial positive reaction was short-lived and important signals regarding the talent deal were left open to receiver interpretation.

For ' $\mathrm{B}$ ' players, our findings bring us to question the prevailing assumption in both research (Dries \& Pepermans, 2008), and practice (Fernández-Aráoz et al., 2011) that strategic ambiguity in communication about talent status is justified to avoid provoking negative reactions. The interviews revealed extensive grapevine activity in the organisation regarding their own talent status as well as others'. This meant that 'B' players were aware of non-status despite receiving no formal information; strategic ambiguity served to enhance their negative reactions by signalling that they were not valued enough to be directly informed. Feeling like one is the last to know seemed to add insult to injury, further increasing the disappointment and negativity, particularly in the egalitarian context of Finland. Our study thus provides some initial insights into 'B' players reactions to their 'non-status', an issue which to date has not received any empirical research attention (De Boeck, Meyers, \& Dries (2018).

Coupled with both talents' and 'B' players' desires for more explicit information about talent pool inclusion criteria, the above is in line with theory on distributive justice. This theory suggests that the perceived fairness of outcomes, as determined by one's own contribution and 
compared with colleagues' (Gelens et al., 2013; Hofmans 2012), may often be equally important in the eyes of employees, if not more, than the actual level of outcomes. Although including only certain people in a talent pool may be perceived unfair, transparency of identification criteria is especially important to maintain perceived distributive justice in the eyes of employees (Brockner \& Weisenfeld, 2005). As suggested by Thibault and Walker (1975), a higher level of perceived fairness and consistency of practices makes people more likely to exhibit positive attitudes to achieve positive outcomes in the future. Furthermore, both talents and 'B' players commented that individual managers had considerable discretion in the matter, and that individual employees could influence this decision through active self-promotion. The unclarity of selection criteria could potentially serve to reinforce such perceptions, which in turn are likely to negatively affect employee perceptions of distributive justice. Such perceptions seemed enhanced in the Finnish context where fairness and modesty is valued in the society. Increased transparency may, thus, contribute to decreasing subjectivity in the talent identification process, both in terms of actual agency of the manager involved in talent identification and in terms of perceived subjectivity and subsequent potential lack of validity of organisational TM in the eyes of employees.

Transparency of criteria for talent pool inclusion further links to the issue of organisations' ethical responsibilities in TM (Swailes, 2013). Talent status can be interpreted as a powerful signal from the organisation regarding the value of individual employees. For talents, there is the possibility of Pygmalion effects (Rosenthal \& Jackson, 1968), as high expectations from the organisation may trigger them to push themselves to perform increasingly well. Conversely, for ' $\mathrm{B}$ ' players, there is a risk of a Golem effect - that they develop perceptions of themselves as inferior due to not being labelled talent, and that their potential is subsequently suppressed (Swailes, 2013). Guest (2017) argues that organisations need to pay attention to the ethical consequences of HRM and should not promote practices that emphasise performance at 
the cost of neglecting responsibilities to employees. This can be particularly challenging but important for MNCs which operate across national borders and often adopt TM systems initiated by the corporate headquarters. Being transparent about what is required to be talent may be one way of alleviating this problem since it clarifies what individual employees need to do to become talent.

In conclusion, we believe our study offers two important contributions to the existing TM literature. First, our focus on both the organisational (strategic ambiguity in talent status communication) and the national (Finnish) contexts helps enhance our understanding of the effectiveness of TM and the extent to which current assumptions and concepts in the TM literature hold true across different contexts. Issues concerning cross-cultural TM communication within different organisational and national contexts remains largely ignored (Dries, 2013). Our findings suggest this is a significant shortcoming since the adoption of an exclusive TM strategy in the largely egalitarian Finnish context, combined with strategic ambiguity in TM communication was clearly seen to affect how signals regarding talent status were received and interpreted by employees. This was evidenced, for example, in the way Finnish values of modesty and egalitarianism translated into a perceived need to tone down one's own achievements, and a distinctive uneasiness with differentiating between people. These culturallyrooted reactions can pose major challenges to both the implementation and effectiveness of exclusive TM.

Second, our focus on employee perceptions is important since HRM practices as such do not influence the attitudes and behaviours of employees, instead these are determined by how employees perceive such practices (Wright \& Nishii, 2007). We examined how strategic ambiguity surfaces for talents and ' $\mathrm{B}$ ' players and found differences both in terms of what there is ambiguity about and at what point in time it surfaces. Overall, our findings suggest only few 
long-term positive effects on the attitudes and behaviours of either group, while they suggest that companies need to be mindful that ambiguity can surface at different points in time and in different ways for different employee groups

\section{Managerial Implications}

The findings of this study also have some practical implications for corporate TM communication policy. First, they lead us to question the effectiveness of strategic ambiguity as a communication approach in terms of building motivation, commitment and all-round positive attitudes amongst talents. Ambiguous and vague communication about the value and content of talent status seems to risk causing frustration. This suggests that communication needs to go beyond the communication of mere status and include unambiguous signals about why they have been included in a talent pool and what the expectations are (and are not). If talents perceive the company to pursue a talent system that does not 'deliver', talent status risks turning into a form of false signalling that employees over time may come to ignore. This potential 'cost' may be precisely what companies want to avoid by pursuing a strategy of strategic ambiguity in the first place, with the rationale that no promises made means no promises broken. This approach, however, risks backfiring if it results in perceptions of reduced credibility of the organisation in terms of not meeting expectations. This is important to note, since talents, despite their exclusive status, are not likely to be any more loyal than other employees; rather, their intention to stay with the company is based on perceptions of career development opportunities within the employing organisation (Höglund, 2012).

Second, with 'B' players, organisations need to acknowledge the fact that most eventually find out about their non-status one way or another. Openness and explicitness about the existence of talent pools may thus be a better approach; organisations may need to be prepared to 
communicate what this means for those not in the pools regarding future development opportunities. Finally, MNCs may also need to make more concerted attempts to understand the meanings attached to exclusive TM practices and how local employees in different parts of the MNC view this status. Alternatives such as 'talent teams', or other forms of positive feedback and status-enhancement such as interesting assignments and opportunities to pursue own projects, may in some contexts be more culturally acceptable than identifying individual talents.

\section{Limitations and Future Research}

This study is naturally subject to certain limitations. First, although the purpose of the study was to explore the employee perspective of TM, one could argue that this should be triangulated with official information on TM from the perspective of the organisation (e.g. corporate HR). While we acknowledge this as a limitation, we nonetheless believe that our information of FinnTech's TM practices is largely accurate since we accessed different groups of employees - that is, both talents and 'B' players. TM implementation, effectiveness and strategic ambiguity are all areas that can be enriched by adopting a stakeholder approach. In line with the multi-actor model presented by King (2015), future research could include different 'communication actors' including top, line and HR managers, and examine the intricacies of arriving at 'signal consistency' in (formal and informal) TM communication amongst multiple signallers.

Secondly, we focus on individuals with experience of TM in the context of one MNC subsidiary in one country. Although this form of strategic ambiguity is likely to be common in many different organisations and countries, the question about the generalisability of our findings to other contexts remains. We believe there are interesting questions around the topic of crosscultural TM communication, which requires a greater problematisation of communication than has thus far been the case. For instance, how effective are transparent versus strategic ambiguity 
approaches to TM communication in cultures that utilise high-context versus low-context communication, or in egalitarian versus non-egalitarian societies? How easy it is to transfer a TM communication strategy from one country context to another within the MNC also remains unexplored. Finally, future studies could adopt truly longitudinal research designs that include how attitudes and behaviours change before, during and after talent status self-awareness.

\section{REFERENCES}

Andersen, P. \& Skaates, M. (2004). Ensuring validity in qualitative international business research. In Welch, C. \& Piekkari, R. (Eds.) Handbook of qualitative research methods for international business. Cheltenham: Edward Elgar.

Barley, S., Meyerson, D. \& Grodal, S. (2011). E-mail as a source and symbol of stress. Organization Science, 22, 887-906.

Bartlett, C. A., \& McLean, A. N. (2003). GE's talent machine: The making of a CEO. Harvard Business School.

Björkman, I., Ehrnrooth, M., Mäkelä, K., Smale, A. \& Sumelius, J. (2013). Talent or not? Employee reactions to talent identification. Human Resource Management, 52, 195-214.

Bowen, D., \& Ostroff, C. (2004). Understanding HRM-firm performance linkages: the role of the "strength" of the HRM system. Academy of Management Review, 29, 204-221.

Brockner, J., \& Wiesenfeld, B. M. (2005). How, when, and why does outcome favourability interact with procedural fairness? In J. Greenberg \& J. A. Colquitt (Eds), Handbook or Organizational justice. Yahweh, NJ: Lawrence Erlbaum

Bryman, A. (2015). Social research methods. Oxford University Press.

Chuai, X., Preece, D., \& Iles, P. (2008). Is talent management just "old wine in new bottles"? The case of multinational companies in Beijing. Management Research News, 31, 901-911.

Church, A. H., Rotolo, C. T., Ginther, N. M., \& Levine, R. (2015). How are top companies designing and managing their high potential programs? A follow-up talent management benchmark study. Consulting Psychology Journal: Practice and Research, 67, 17-47.

Claussen, J., Grohsjean, T., Luger, J., \& Probst, G. (2014). Talent management and career development: What it takes to get promoted. Journal of World Business, 49, 236-244.

Collings, D. G., Scullion, H., \& Vaiman, V. (2011). European perspectives on talent management. European Journal of International Management, 5, 453-462.

Collings, D.G., \& Mellahi, K. (2009). Strategic talent management: A review and research agenda. Human Resource Management Review, 19, 304-313.

De Boeck, G., Meyers, M.C., \& Dries, N. (2018). Employee reactions to talent management: assumptions vs. evidence. Journal of Organizational Behavior, 39, 199-213.

Delong, T. J., \& Vijayaraghavan, V. (2003). Let's hear it for B players. Harvard Business Review, 81, 96-103. 
Dries, N. (2013). The psychology of talent management: A review and research agenda. Human Resource Management Review, 23, 272-285.

Dries, N. \& De Gieter, S. (2014). Information asymmetry in high potential programs: A potential risk for psychological contract breach, Personnel Review, 43, 136-162.

Dries, N., \& Pepermans, R. (2008). 'Real' high potential careers: An empirical study into the perspectives of organizations and high potentials. Personnel Review, 37(1), 85-108.

Ehrnrooth, M., Björkman, I., Mäkelä, K., Smale, A., Sumelius, J., \& Taimitarha, S. (forthcoming). Talent Responses to Talent Status Awareness - Not a Question of Simple Reciprocation. Human Resource Management Journal.

Fernández-Aráoz, C., Groysberg, B., \& Nohria, N. (2011). How to hang on to your high potentials. Harvard Business Review, 89, 76-83.

Festing, M., Kornau, A., \& Schäfer, L. (2015). Think talent-think male? A comparative case study analysis of gender inclusion in talent management practices in the German media industry. International Journal of Human Resource Management, 26, 707-732.

Gallardo-Gallardo, E., Dries, N., \& González-Cruz, T. F. (2013). What is the meaning of 'talent' in the world of work?. Human Resource Management Review, 23, 290-300.

Gallardo-Gallardo, E., \& Thunnissen, M. (2016). Standing on the shoulders of giants? A critical review of empirical talent management research. Employee Relations, 38, 31-56.

Gelens, J., Dries, N., Hofmans, J., \& Pepermans, R. (2013). The role of perceived organizational justice in shaping the outcomes of talent management: A research agenda. Human Resource Management Review, 23, 341-353.

Gelens, J., Hofmans, J., Dries, N. and Pepermans, R. (2014). TM and organizational justice: employee reactions to high potential identification. Human Resource Management Journal, 24, 159-175.

Guest, D.E. (2107). Human Resource Management and Employee Well-being: Towards a New Analytic Framework. Human Resource Management Journal, 27(1), 22-38.

Guest, D. E., \& Conway, N. (2002). Communicating the psychological contract: An employer perspective. Human Resource Management Journal, 12: 22-38.

Guzzo, R. A., \& Noonan, K. A. (1994). Human resource practices as communications and the psychological contract. Human Resource Management, 33, 447-462.

Hofmans, J. (2012). Individual differences in equity models. Psycologica, 33, 473-482.

Höglund, M. (2012). Quid pro quo? Examining talent management through the lens of psychological contracts. Personnel Review, 41, 126-142.

Khilji, S. E., Tarique, I., \& Schuler, R. S. (2015). Incorporating the macro view in global talent management. Human Resource Management Review, 25, 236-248.

King, K. A. (2016). The talent deal and journey: Understanding how employees respond to talent identification over time. Employee Relations, 38, 94-111.

Lanvin, B., \& Evans, P. (2018). Diversity for Competitiveness. The Global Talent Competitiveness Index, INSEAD.

Maitlis, S. \& Lawrence, T.B (2007). Triggers and enablers of sensegiving in organizations. Academy of Management Journal, 50, 57-84

Malik, A.R. \& Singh, P. (2014). 'High potential' programs: Let's hear it for 'B' players.' Human Resource Management Review, 24, 330-346.

Miles, J. \& Gilbert, P. (2005). A Handbook of Research Methods for Clinical and Health Psychology. Oxford University Press. 
Nijs, S., Gallardo-Gallardo, E., Dries, N., \& Sels, L. (2014). A multidisciplinary review into the definition, operationalization, and measurement of talent. Journal of World Business, 49, 180-191.

Nishii, L. H., Lepak, D. P., \& Schneider, B. (2008). Employee attributions of the "why" of HR practices: Their effects on employee attitudes and behaviors, and customer satisfaction. Personnel Psychology, 61, 503-545.

Patton, M. (2015). Qualitative Research and Evaluation Methods, $4^{\text {th }}$ edn. Thousand Oaks, CA: Sage.

Petriglieri, J. \& Petriglieri, G. (2017). The talent curse. Harvard Business Review, May-June, 8894.

Pratt, M. G. (2009). From the editors: For the lack of a boilerplate: Tips on writing up (and reviewing) qualitative research. Academy of Management Journal, 52(5), 856-862.

Rosenthal, R., \& Jacobson, L. (1968). Pygmalion in the classroom. The Urban Review, 3(1), 1620.

Sahlberg, P. (2015). Finnish lessons 2.0: What can the world learn from educational change in

Finland? Teachers College Press: New York.

Sandemose, A. (1933). En flyktning krysser sitt spor: fortelling om en morders barndom (Vol. 28). Gyldendal.

Silzer, R., \& Church, A. H. (2009). The pearls and perils of identifying potential. Industrial and Organizational Psychology, 2(4), 377-412.

Silzer, R.F. \& Church, A.H. (2010). Identifying and assessing high potential talent: current organizational practices. In Silzer, R.F. \& Dowell, B.E. (Eds), Strategy Driven TM: A Leadership Imperative, Jossey Bass, San Francisco, CA.

Slan-Jerusalim, R., \& Hausdorf, P. A. (2007). Managers' justice perceptions of high potential identification practices. Journal of Management Development, 26(10), 933-950.

Sonnenberg, M., van Zijderveld, V., \& Brinks, M. (2014). The role of talent-perception incongruence in effective talent management. Journal of World Business, 49(2), 272-280.

Starbuck, W.H. \& Milliken, F.J. (1988). Executives' Perceptual Filters: What They Notice and How They Make Sense. In Hambrick, D. (Ed.) The Executive Effect: Concepts and Methods for Studying Top Managers. Greenwich. CT: JAI Press.

Strauss, A., Corbin, J., 1998. Basics of Qualitative Research: Grounded Theory Procedures and Technique, 2nd Edition. Sage, Newbury Park, London.

Suazo, M. M., Martínez, P. G., \& Sandoval, R. (2009). Creating psychological and legal contracts through human resource practices: A signaling theory perspective. Human Resource Management Review, 19, 154-166.

Swailes, S. (2013). The ethics of talent management. Business Ethics: A European Review, 22, $32-46$.

Swailes, S., \& Blackburn, M. (2016). Employee reactions to talent pool membership. Employee Relations, 38, 112-128.

Tansley, C., \& Tietze, S. (2013). Rites of passage through talent management progression stages: an identity work perspective. International Journal of Human Resource Management, 24(9), 1799-1815.

Thibault, J. \& Walker, L. (1975). Procedural justice: A psychological analysis. Hillsdale, NJ: Erlbaum.

Thunnissen, M., Boselie, P., \& Fruytier, B. (2013). Talent management and the relevance of context: Towards a pluralistic approach. Human Resource Management Review, 23, 326336. 
Wright, P. \& Nishii, L. (2007). Strategic HRM and organizational behavior: Integrating multiple levels of analysis (CAHRS Working Paper \#07-03). Ithaca, NY: Cornell University, School of Industrial and Labor Relations, Center for Advanced Human Resource Studies. http://digitalcommons.ilr.cornell.edu/cahrswp/468. 
Table 1. Data-coding examples

\begin{tabular}{|c|c|}
\hline Coding Examples & \\
\hline Interview excerpt & $\begin{array}{l}\text { "..I think it's clear for the HR person or maybe it's clear for the one who is } \\
\text { managing the whole program, but for the people who are in the program, it's never } \\
\text { been. I've been in two programs and it's really the case that all the time I'm crazy } \\
\text { proud that I'm talent, wow, but what does it mean? Do I get a t-shirt? Obviously } \\
\text { not, which is good, but I, like, I don't know. Where does it start, where does it end, } \\
\text { I don't know..." }\end{array}$ \\
\hline Interviewee & Interviewee \# 1, current employee and member of a talent pool \\
\hline Interpretation & Interviewee \#1 is not aware of what being identified as talent means \\
\hline Coded as & $\begin{array}{l}\text { One piece of evidence that FinnTech does not communicate the implications of } \\
\text { talent status to members of talent pools }\end{array}$ \\
\hline Interview excerpt & $\begin{array}{l}\text { "If we're talking about a key talent group, it's not prominently announced so that } \\
\text { these and these people are in the group this year, yet there are certain programs that } \\
\text { those people get involved in, that have high visibility. So if you put two and two } \\
\text { together, people can identify those individuals through the projects that they're } \\
\text { working on." }\end{array}$ \\
\hline Interviewee & Interviewee \#6, current employee and member of a talent pool \\
\hline Interpretation & $\begin{array}{l}\text { Interviewee \#6 says that despite FinnTech not openly communicating about } \\
\text { talent status people can figure out who is in a talent pool. }\end{array}$ \\
\hline Coded as & $\begin{array}{l}\text { One piece of evidence that employees find out about TM and talent status through } \\
\text { informal channels of communication }\end{array}$ \\
\hline Interview excerpt & $\begin{array}{l}\text { "Umm, I would almost say that, you know, you're proud, it's a bit stressful as well, } \\
\text { because you do know that you're not the one in the group anymore, you're } \\
\text { basically, you stick out. So you do need to be a bit more careful with wordings and } \\
\text { stuff, like when you have discussions with upper management..." }\end{array}$ \\
\hline Interviewee & Interviewee \#12, former employee and member of a talent pool \\
\hline Interpretation & $\begin{array}{l}\text { Interviewee \#12 describes feelings of pressure upon hearing that she has been } \\
\text { recognized as talent }\end{array}$ \\
\hline Coded as & $\begin{array}{l}\text { One piece of evidence that talent status is also associated with feelings of pressure } \\
\text { due to the increased visibility for top management that follows with talent status. }\end{array}$ \\
\hline Interview excerpt & $\begin{array}{l}\text { "...I think it's more like a secret club, which makes it a little bit weird. I think it } \\
\text { would be good for all employees to know that we have something like this, } \\
\text { because then they would think that 'ok, I want to be part of that', and then, if they } \\
\text { understood the selection criteria, then they would know how to get in if they would } \\
\text { want to get in" }\end{array}$ \\
\hline Interviewee & Interviewee $\# 1$, a current employee and member of a talent pool \\
\hline Interpretation & Interviewee \#1 describes the secretive nature of TM in FinnTech \\
\hline Coded as & $\begin{array}{l}\text { One piece of evidence that FinnTech does not communicate openly to employees } \\
\text { about TM or the criteria for gaining talent status. }\end{array}$ \\
\hline
\end{tabular}


Figure 1. Reactions and sensemaking of talent about their talent status

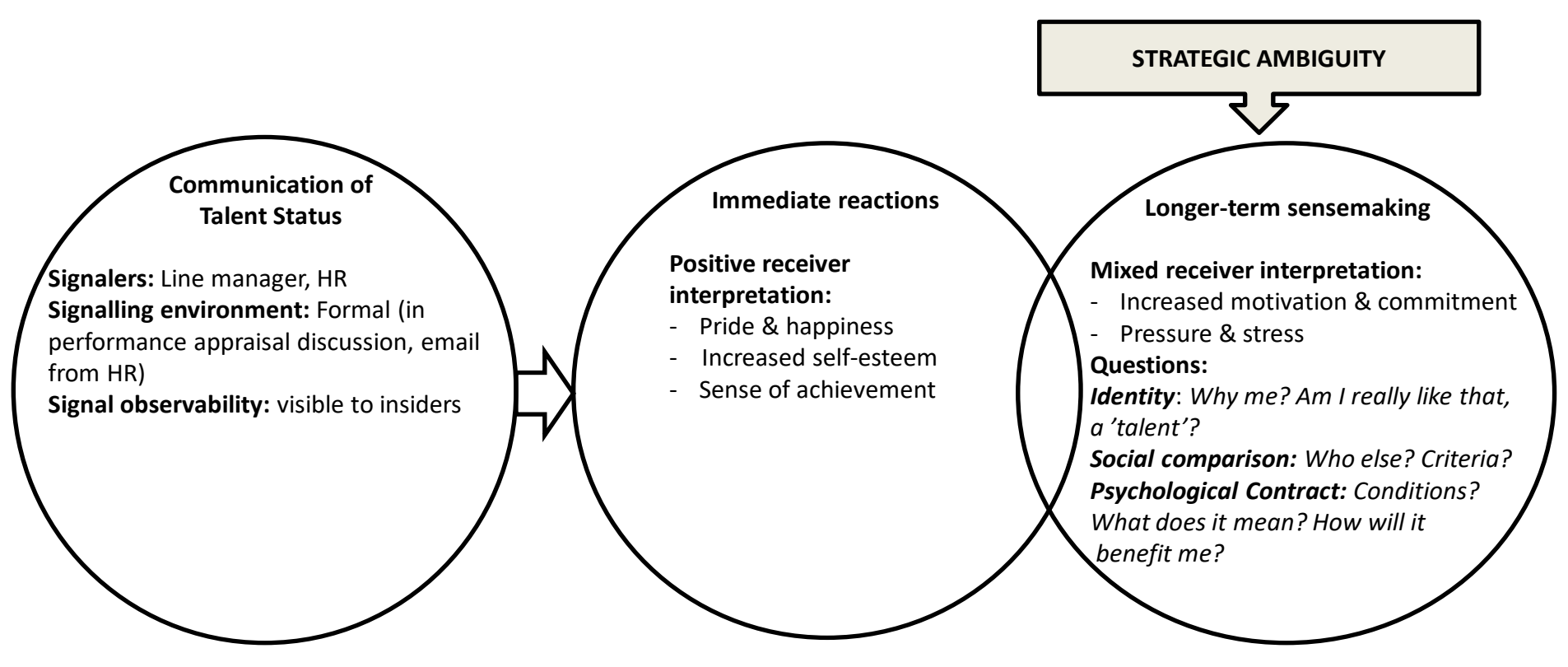


Figure 2. Reactions and sensemaking of 'B' players about their talent status

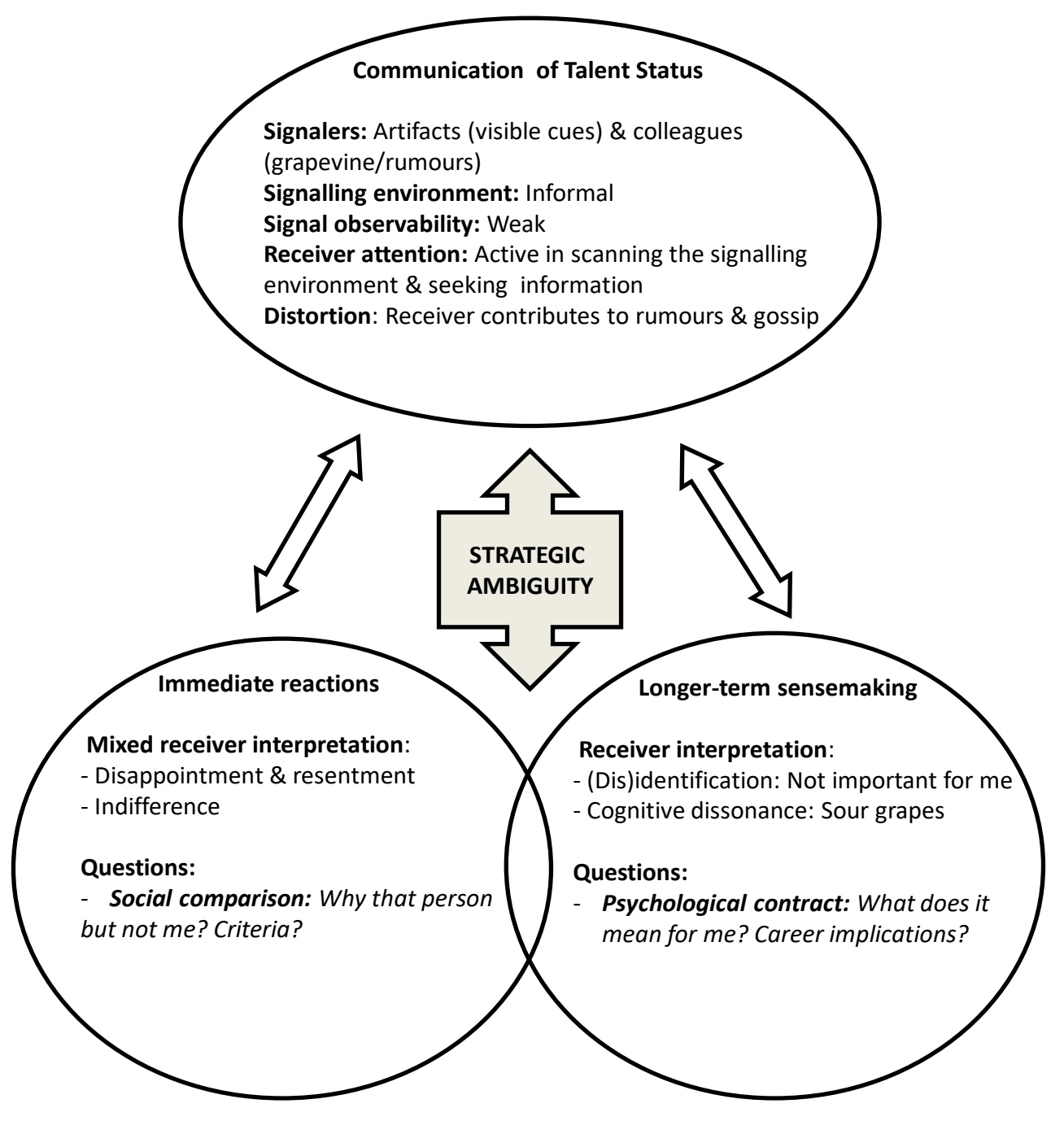

